\title{
Microalgae biopeptides applied in nanofibers for the development of active packaging
}

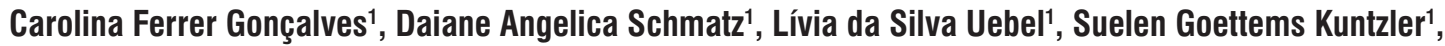 \\ Jorge Alberto Vieira Costa ${ }^{2}$, Karine Rigon Zimmer ${ }^{1}$ and Michele Greque de Morais ${ }^{1 *}$
}

${ }^{1}$ Laboratory of Microbiology and Biochemistry, College of Chemistry and Food Engineering, Universidade Federal do Rio Grande - FURG, Rio Grande, RS, Brazil

${ }^{2}$ Laboratory of Biochemical Engineering, College of Chemistry and Food Engineering, Universidade Federal do Rio Grande - FURG, Rio Grande, RS, Brazil

*michele.morais@pq.cnpq.br

\begin{abstract}
This study was conducted to develop PCL nanofibers with the incorporation of microalgae biopeptides and to evaluate the stability of chicken meat cuts during storage. PCL and PCL/biopeptides nanofibers were formed by electrospinning method, and the diameters obtained were 404 and $438 \mathrm{~nm}$, respectively. The tensile strength, elongation, melting temperature and thermal stability of biopeptide-added PCL nanofibers were $0.245 \mathrm{MPa}, 64 \%, 56.8{ }^{\circ} \mathrm{C}$ and $318{ }^{\circ} \mathrm{C}$, respectively. PCL/biopeptide nanofibers showed a reducing power of 0.182 , inhibition of $22.6 \%$ and $12.4 \%$ for DPPH and ABTS radicals, respectively. Chicken meat cuts covered by the PCL/biopeptide nanofibers showed $0.98 \mathrm{mgMDA} \cdot \mathrm{kg}^{-1}$ and $25.8 \mathrm{mgN} \cdot 100 \mathrm{~g}^{-1}$ for TBARS and $\mathrm{N}-\mathrm{BVT}$ analysis, respectively. Thus, the PCL/biopeptide nanofibers provided greater stability to the product and control of oxidative processes ensuring the product quality maintenance during the $12 \mathrm{~d}$ of storage.
\end{abstract}

Keywords: antioxidants, electrospinning, poly-c-caprolactone.

\section{Introduction}

The conservation of fresh meat products is an important factor in ensuring food safety to the final consumer. Due to the lipid and protein content, these products are targets of lipid oxidation that result in nutritional changes by the degradation of fat-soluble vitamins and essential fatty acids ${ }^{[1,2]}$. New technologies have been employed to improve the quality and extend the shelf life of food products. The use of active packaging is one such technology and consists in the action of antioxidants and antimicrobial compounds that interact with food ${ }^{[3,4]}$. There are several mechanisms of action of these agents that include absorption of carbon dioxide, oxygen, ethylene and odors. Furthermore, compounds such as antimicrobials and antioxidants that retard the degradation processes in food have been used in packaging ${ }^{[5-7]}$.

In the food industry, many synthetic antioxidants such as butyl hydroxy toluene (BHT) and butyl hydroxy anisole (BHA) are used to slow the peroxidation processes. However, the use of these compounds must be controlled due to the carcinogenic effects on human health ${ }^{[8]}$. Thus, the search for natural antioxidants is a safer alternative for use in food.

Microalgae are capable of synthesizing many bioactive compounds. These include lipids, carotenoids and phycobiliproteins. The biopeptides of microalgal source have applications as dietary supplements, health promoters and more recently they have been suggested for inclusion in active packaging ${ }^{[9]}$. Spirulina is a cyanobacterium that has GRAS (Generally Recognized As Safe) certification, with high protein content and is a source of biopeptides with antioxidant activity ${ }^{[10]}$. The biopeptides are protein fragments that contain 3 to 20 amino acid residues that are inactive within the protein molecule and can be released by hydrolysis ${ }^{[11]}$. The application studies of biopeptides of microalgal source are restricted in the packaging area for food preservation ${ }^{[12]}$.

The nanofibers can be applied to food preservation. Packaging formed by nanofibers have advantages for allowing an increase of the contact area of the product with bioactive compounds. The incorporation of biopeptides in the matrix of nanofibers has the aim of inferring improvements in performance and in the physical and active properties of carriers. Nanofiber packages are alternatives to increase food shelf life to the end consumer ${ }^{[13]}$.

Nanofibers can also be developed from biodegradable polymers. This reduces the environmental problems caused by the disposal of packaging developed from polymers of petrochemical origin ${ }^{[14-16]}$. In this sense, the objective of this study was to develop nanofibers with the incorporation of antioxidant biopeptides of microalgal source for the conservation of chicken meat.

\section{Materials and Methods}

\subsection{Obtaining biopeptides by enzymatic hydrolysis of the Spirulina sp. LEB 18 biomass}

Spirulina sp. LEB 18 biomass was obtained from the pilot plant of the Laboratory of Biochemical Engineering, located in the city of Santa Vitória do Palmar, Rio Grande do $\mathrm{Su}^{[17]}$. The biomass was concentrated in a hydraulic 
press, dried at $50^{\circ} \mathrm{C}$, ground in a ball mill (QUIMIS Q298), sieved (ABNT/Tyler 60) and kept at $-18^{\circ} \mathrm{C}$.

Protein hydrolysis was carried out in $100 \mathrm{~mL}$ reactors using $3 \%$ of the microalgae biomass solubilized in sodium carbonate bicarbonate buffer $\mathrm{pH} 9.5$ and $3 \mathrm{U} \cdot \mathrm{mL}^{-1}$ of Protemax 580 L enzyme, courtesy of Prozyn (São Paulo). The process was conducted at $60{ }^{\circ} \mathrm{C}$ under agitation of $180 \mathrm{rpm}$ for $240 \mathrm{~min}$. The final reaction was heat inactivated at $85{ }^{\circ} \mathrm{C}$ bath for $10 \mathrm{~min}$. The degree of hydrolysis (DH) was determined by the protein content before and after the process, according to the method described by Hoyle and Merrit ${ }^{[18]}$. The protein hydrolysates were filtered through qualitative membranes of $0.45 \mu \mathrm{m}, 0.22 \mu \mathrm{m}$ and $0.1 \mu \mathrm{m}$ and Amicon ${ }^{\circledR} 10 \mathrm{~K}$ vertical column. After this step the samples were lyophilized.

\subsection{Development of nanofibers}

Polycaprolactone (PCL) polymer obtained from Sigma Aldrich $^{\circledR}$ (density of $1.145 \mathrm{~g} \cdot \mathrm{mL}^{-1}$ and molecular weight of $80,000 \mathrm{~g} \cdot \mathrm{mol}^{-1}$ ) was used in preparing polymer solutions for the development of nanofibers. The solution contained $12 \%$ (w/v) PCL, $1.4 \%(\mathrm{w} / \mathrm{v}) \mathrm{NaCl}, 3 \%(\mathrm{w} / \mathrm{v})$ biopeptides using chloroform:methanol $(1: 3, \mathrm{v} / \mathrm{v})$ as solvent for the solubilization of the compounds in the polymeric solution. The control solution was prepared under the same conditions, containing only PCL and $\mathrm{NaCl}$. The solutions were homogenized in a magnetic stirrer for $12 \mathrm{~h}\left(25^{\circ} \mathrm{C}\right)$.

The PCL and biopeptide-added PCL solutions from microalgal source were placed in syringe with capillary of $0.70 \mathrm{~mm}$ diameter and injected across infusion pump (KD Scientific, KDS 100, USA). The potential difference between capillary and collector caused evaporation of the solvent and the nanofibers were deposited on the collector. The distance between the capillary and collector was $120 \mathrm{~mm}$, electric potential of $25 \mathrm{kV}$, and solution feed rate of $2000 \mu \mathrm{L} \cdot \mathrm{h}^{-1}$. The process environment condition was $25^{\circ} \mathrm{C}$ and relative humidity $44 \%$. The nanofibers were formed using a solution volume of $2 \mathrm{~mL}$. After the process, the nanofibers were collected and stored in a desiccator under controlled humidity (20\% R.H).

\subsection{Evaluation of developed nanofibers}

Analysis were performed on samples of PCL (control) and biopeptide-added PCL nanofibers. The nanofibers were analyzed in a scanning electron microscope (SEM) (JEOL JSM-6610 LV, Japan). The diameters were determined using 30 readings of nanofibers. The samples were fixed in a metallic support and coated with gold using diode sputtering (Denton Vacuum CAR001-0038, USA) according to ASTM E986-04 ${ }^{[19]}$

The viscosity of the polymeric solutions was determined by rheometer (Brookfield Programmable DV-III Ultra Rheometer, USA). This analysis consists of the direct measurement of the viscosity of PCL and biopeptide-added PCL solutions.

The melting temperatures and enthalpies were determined by analysis of differential scanning calorimetry (DSC) (Shimadzu DSC-60, Japan). A sample of $3 \mathrm{mg}$ of nanofibers was placed under nitrogen atmosphere and flow of $50 \mathrm{~mL} \cdot \mathrm{min}^{-1}$. The analysis were conducted at range between $25^{\circ} \mathrm{C}$ and $180{ }^{\circ} \mathrm{C}$, at heating rate of $10{ }^{\circ} \mathrm{C} \cdot \mathrm{min}^{-1}$.
The melting temperature was determined from the peak shown in the DSC melting curve ${ }^{[20]}$.

The thermal stability of nanofibers, and residual solvent was carried out in thermogravimetric analyzer (Shimadzu DTG-60, Japan) according to ASTM D3850-12 protocol $^{[21]}$. Analysis were conducted from 25 to $500{ }^{\circ} \mathrm{C}$ under an inert nitrogen atmosphere with a flow rate of $30 \mathrm{~mL} \cdot \mathrm{min}^{-1}$ and constant heating rate of $10{ }^{\circ} \mathrm{C} \cdot \mathrm{min}^{-1}$ using $3 \mathrm{mg}$ of sample.

The tensile strength and elongation at break of the nanofibers were measured by a texturometer (Stable Micro Systems Model TA.XT plus, England). Samples were prepared with dimensions of $10 \times 70 \mathrm{~mm}$ and thickness measured in a micrometer (Starrett 444MXRL-75, Brazil). Assays were performed at speeds of $2 \mathrm{~mm} \cdot \mathrm{s}^{-1}$ and initial distance between grips of $50 \mathrm{~mm}$.

The tensile strength and elongation at break were calculated according to Equations 1 and 2.

$$
T_{s}=\frac{F_{m}}{A}
$$

where: $\mathrm{T}_{\mathrm{s}}=$ tensile strength $(\mathrm{MPa}) ; \mathrm{F}_{\mathrm{m}}=$ maximum force at the time of rupture of the nanofibers $(\mathrm{N}) ; \mathrm{A}=$ cross-sectional area $\left(\mathrm{m}^{2}\right)$.

$$
\varepsilon=100 \frac{d_{r}}{d_{i}}
$$

where: $\varepsilon=$ elongation at break $(\%) ; d_{I}=$ initial separation distance $(\mathrm{mm}) ; d_{R}$ is the difference between the separation distance at the time of rupture and the initial distance.

The antioxidant activity was determined for the Spirulina sp. LEB 18 biomass, biopeptides as well as the PCL and biopeptide-added PCL nanofibers were filtered through Amicon ${ }^{\circledR} 10 \mathrm{~K}$ column. The methods evaluated the reducing power ${ }^{[22]}$ and sequestration capacity of the free radical DPPH (2,2-diphenyl-1-picryl-hidrazol $)^{[23]}$, and ABTS (2,2'-azino-bis(3-ethylbenzothiazoline-6-sulfonic acid) $)^{[24]}$. The measurements were expressed as inhibition percentage (Equation 3).

$$
\% \text { Inhibition }=\left(\frac{A B S_{\text {blank }}-A B S_{\text {sample }}}{A B S_{\text {blank }}}\right) \times 100
$$

The biomass solution and biopeptides were prepared at a concentration of $10 \mathrm{mg} \cdot \mathrm{mL}^{-1}$ for analysis of the reducing power methods and sequestering of ABTS free radical. In DPPH free radical sequestration analysis, solutions were prepared at a concentration of $5 \mathrm{mg} \cdot \mathrm{mL}^{-1}$. For the nanofibers, $50 \mathrm{mg}$ of the nanofiber samples were solubilized with the addition of $5 \mathrm{~mL}$ methanol and $2 \mathrm{~mL}$ of chloroform for the rupture of the structure and extraction of biopeptides. The true concentration of biopeptides in the matrix of nanofibers analyzed for antioxidant activity corresponded to $0.21 \mathrm{mg} \cdot \mathrm{mL}^{-1}$. The solutions were homogenized by vortex for $1 \mathrm{~min}$.

\subsection{Application of bioactive nanofibers and evaluation of the stability of chicken meat cuts during storage}

In the analysis of stability, cuts of the same chicken breast sample of approximately $90 \mathrm{~g}$ each were done. A sample was coated with the nanofiber matrix containing biopeptides and another sample was left without coverage for $12 \mathrm{~d}$, the 
validity period for commercial poultry. Samples were then cut and homogenized for analysis.

The stability of chicken breasts stored under refrigeration $\left( \pm 6^{\circ} \mathrm{C}\right)$ with the nanofibers containing biopeptides and without nanofibers was evaluated by the test of reactive species to the 2-thiobarbituric acid (TBARS) with modifications ${ }^{[25]}$. Chicken breast samples with a mass of $50 \mathrm{~g}$ were cut out and homogenized with $100 \mathrm{~mL}$ of $7.5 \%$ trichloroacetic acid (TCA) for $20 \mathrm{~min}$ in a mixer, vacuum filtered and the volume completed to $100 \mathrm{~mL}$ in a volumetric flask. A $5 \mathrm{~mL}$ aliquot of the filtrate was mixed with $5 \mathrm{~mL}$ of $0.02 \mathrm{M}$ thiobarbituric acid (TBA) in test tube covered with an aluminum foil and placed on a water bath for $30 \mathrm{~min}$ at $80^{\circ} \mathrm{C}$. The analysis of the blank containing $5 \mathrm{~mL}$ of $7.5 \%$ TCA and $5 \mathrm{~mL}$ of TBA was carried out parallel to the assays. Soon after, the reading was carried out by spectrophotometer at $538 \mathrm{~nm}$. The TEP (tetraethoxypropane) standard curve was used for the quantification of TBARS. The evaluations were performed in two stages: at time zero and after $12 \mathrm{~d}$ of storage. Nanofiber matrices were removed from chicken samples for analysis.

The determination of total volatile bases (N-BVT) it was made in chicken cuts kept under refrigeration $\left( \pm 6^{\circ} \mathrm{C}\right)^{[26]}$. A sample of approximately $50 \mathrm{~g}$ was blended with $100 \mathrm{~mL}$ of $7.5 \%$ TCA for 20 min on a mixer, vacuum filtered and the volume completed to $100 \mathrm{~mL}$ in a volumetric flask. An aliquot of $10 \mathrm{~mL}$ of the extracts was transferred to micro Kjeldahl distillation tube, 3 drops of phenolphthalein were added and it was subjected to distillation. The distillate was collected in $5 \mathrm{~mL}$ of boric acid $\left(50 \mathrm{~g} \cdot \mathrm{L}^{-1}\right)$ with 4 drops of bromocresol green and methyl red indicator (30:20). The titration was performed with a $0.02 \mathrm{~N}$ hydrochloric acid solution. The calculation was performed according to Equation 4, and expressed in $\mathrm{mgN} \cdot 100 \mathrm{~g}^{-1}$ sample.

$N-B V T=\frac{\left(V_{\text {HClsample }}-V_{H C l \text { lalank }}\right) \times N_{H C l} \times 14.01 \times 100}{P_{\text {sample }}}$

where in: $\mathrm{V}_{\mathrm{HCl}}=$ volume $(\mathrm{mL})$ used in the titration; $\mathrm{N}_{\mathrm{HCl}}=$ normality of $\mathrm{HCl} ; \mathrm{P}_{\text {sample }}=$ mass of sample $(\mathrm{g})$.

\subsection{Statistical analysis}

Analysis were performed in triplicate and the results were evaluated by analysis of variance (ANOVA) one-way at the $95 \%$ level of confidence.

\section{Results and Discussion}

The apparent viscosities of the PCL and biopeptide-added PCL solutions were $221.2 \pm 5.1 \mathrm{mPa} \cdot \mathrm{s}^{-1}$ and $243.1 \pm 12.0 \mathrm{mPa} \cdot \mathrm{s}^{-1}$, respectively, and made the formation of cylindrical nanofibers possible without forming droplets. The small increase in viscosity can be due to the presence of methanol, which according to product specifications shows higher viscosity $\left(600 \mathrm{mPa} \cdot \mathrm{s}^{-1}\right)$ than chloroform $\left(580 \mathrm{mPa} \cdot \mathrm{s}^{-1}\right)$. Besides that, this increase on viscosity is related with polarity of chloroform present in greater proportion on solution, making it difficult to solubilize the biopeptide which is a polar molecule. These solution characteristics are important for the electrospinning process because they prevent the formation of drops and allow the continuous jet of polymer solution to form nanofibers with greater uniformity ${ }^{[27]}$.

PCL $10 \%(\mathrm{w} / \mathrm{v})$ solutions used by Ranjbar-Mohammadi and Bahrami ${ }^{[28]}$ showed apparent viscosity ranging from $700 \mathrm{mPa} \cdot \mathrm{s}^{-1}$. The authors developed nanofibers by electrospinning with a distance of $150 \mathrm{~mm}$ between the capillary and collector, electric potential of $15 \mathrm{kV}$ and flow rate of $2000 \mu \mathrm{L} \cdot \mathrm{h}^{-1}$, presenting an average diameter of $156 \mathrm{~nm}^{[28]}$. The values in the present study are in agreement, the difference in viscosity can be associated with the addition of methanol for solubilization of the biopeptides in the PCL solution. The addition of methanol helped to increase the polarity solution, however, the added methanol fraction was less than chloroform and therefore did not provide complete homogenization of the solution, that can also have increased viscosity.

PCL and biopeptide-added PCL nanofibers produced by electrospinning were observed by SEM (Figure 1) to verify the form and the average diameter. Cylindrical nanofibers were obtained in a nanometer scale with diameter

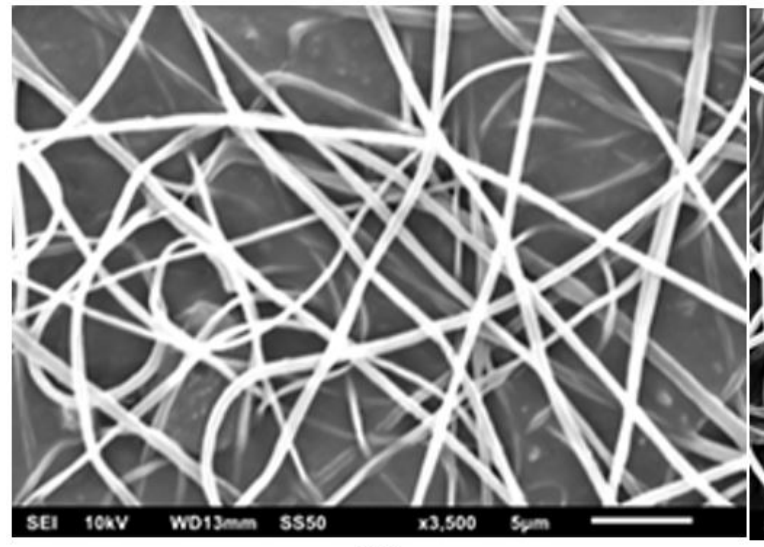

(a)

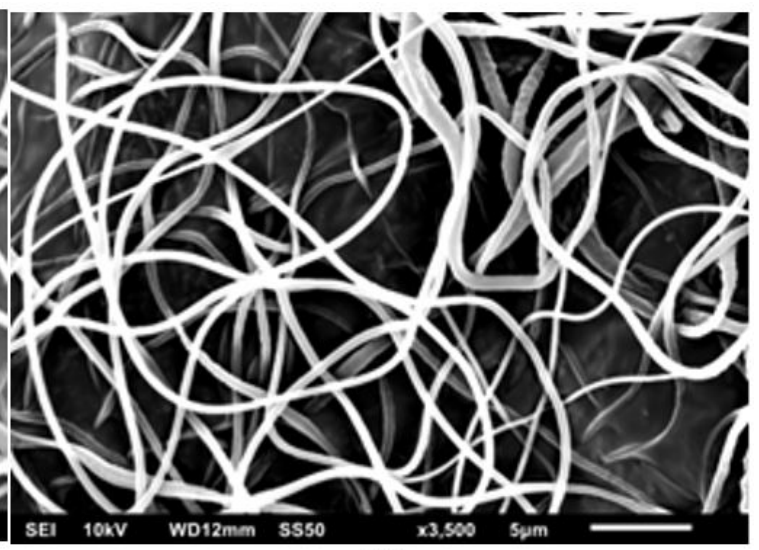

(b)

Figure 1. Nanofibers with $12 \%$ PCL, $1.4 \% \mathrm{NaCl}$ (a) and 12\% PCL, $1.4 \% \mathrm{NaCl}$, methanol and 3\% Spirulina sp. LEB 18 biopeptides (b) under magnification of 3500x. 
uniform, which can be confirmed by the standard deviations. The diameters of the nanofibers were $404 \pm 72 \mathrm{~nm}$ and $438 \pm 24 \mathrm{~nm}$ for PCL and biopeptide-added PCL respectively. The diameter of nanofibers containing the biopeptides did not differ significantly at $95 \%$ confidence in relation to the PCL nanofibers.

This study showed similar results to that developed by Goes et al. ${ }^{[29]}$. The authors obtained nanofibers from 15\% PCL solution with addition of $2.5 \%$ clay and resulted in an average diameter of $340 \mathrm{~nm}^{[29]}$. Furthermore, the solutions were prepared by mixing chloroform and methanol as in this study. Thus, the conductivity characteristics were improved due to the increased polarity of the solution by the presence of methanol and salt. Wu et al. ${ }^{[7]}$, obtained PCL fibers with the addition of $20 \%(\mathrm{w} / \mathrm{w})$ polyaniline without formation of droplets with a diameter of $150 \mathrm{~nm}$. The solutions were also prepared with a mixture of chloroform and methanol.

According to DSC analysis data, only one transition peak was presented for the PCL and biopeptide-added PCL samples (Figure 2). The DSC analysis resulted in a first-order endothermic event that may result from processes such as breaking bonds, decomposition and volatilization. Table 1 shows the melting point values ( $\left.\mathrm{T}_{\text {melting }}\right)$ and enthalpy for PCL and biopeptide-added PCL. The enthalpy is closely related to the amount of energy absorbed by the samples for the change of state to occur.

Campos et al. ${ }^{[30]}$ evaluated the thermal properties of extruded PCL films and reported that the $\mathrm{T}_{\text {melting }}$ was $56.36^{\circ} \mathrm{C}$ being in accordance with the values of this study. In addition, they report that the glass transition temperature of PCL is in the range of $-60{ }^{\circ} \mathrm{C}$. From this information, it is possible to set the applicability range of PCL as food packaging for chilled products or at room temperature, since the temperatures do not exceed the limits of the change of state of nanometer material.

In a study by Wang et al. ${ }^{[31]}$ it was found that changes in $\mathrm{T}_{\text {melting }}$ in PCL nanofibers alter the crystallinity of the polymer and consequently the biodegradation process. Moreover, they observed that the solvent is evaporated lasting through the electrospinning process and even after deposition of the nanofibers on the collector and the residual solvent continues to evaporate. Thus, the use of nanofibers as food packaging becomes secure. In a study of PCL blends associated with polysaccharides, Ciardeli et al. ${ }^{[32]}$ obtained a reduction in $\mathrm{T}_{\text {melting }}$ values of the samples when compared to the PCL film due to the interactions of the compounds incorporated into the polymer.

In the derivative curves (Figure 3 ), the biopeptide-added PCL nanofibers showed (Table 1) initial and final thermal degradation temperature smaller compared to PCL nanofibers. This might have occurred, because of the biopeptides sensibility which, being natural compound, degrade more easily at high temperatures, different from what happens with PCL that is a synthetic polymer with higher thermal stability. Therefore, the biopeptides addition in PCL nanofibers caused the decrease on degradation temperature. Furthermore, there was no degradation peak in the range of $60^{\circ} \mathrm{C}$, however, it is found that no residue of chloroform and methanol solvents are in the nanofibers, being completely evaporated after the electrospinning process.

The changes in the temperatures of degradation of nanofibers containing biopeptides may be a consequence crystallinity change of the PCL caused by addition natural compounds that are degraded at lower temperatures. Ciardeli et al. ${ }^{[32]}$ also observed similar behavior with $\mathrm{PCL} /$ polysaccharides blends reported reduction in temperature in the pyrolysis compared to pure PCL films. Patrício et al. ${ }^{[33]}$ obtained thermal stability temperatures values of up to $300{ }^{\circ} \mathrm{C}$ for polymer blends of PCL and PLA.

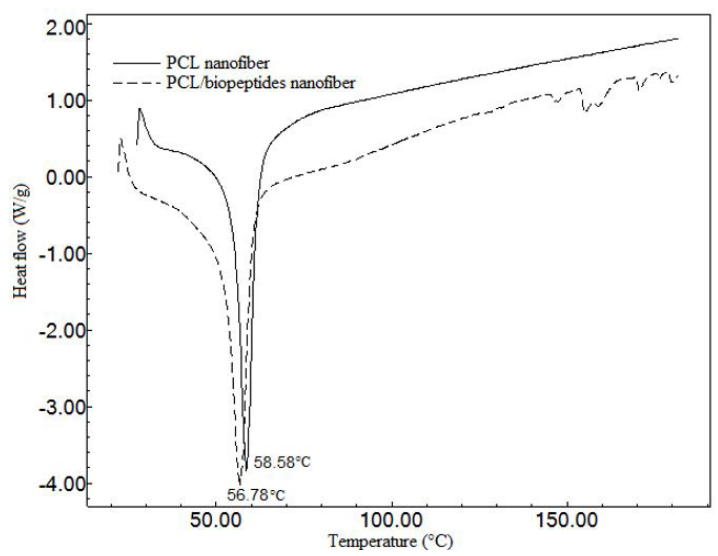

Figure 2. DSC curves for nanofiber PCL and biopeptide-added PCL.

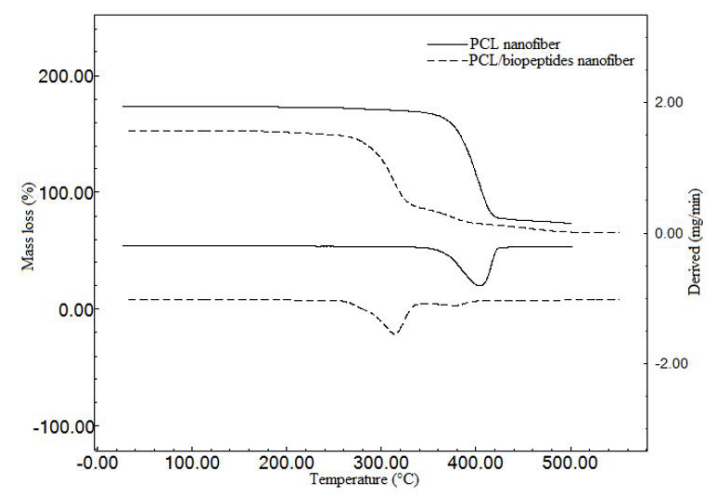

Figure 3. TGA curves for nanofiber PCL and biopeptide-added PCL.

Table 1. Thermal properties of DSC and TGA of PCL and biopeptide-added PCL nanofibers.

\begin{tabular}{cccccc}
\hline Sample & $\mathbf{T}_{\text {melting }}\left({ }^{\circ} \mathbf{C}\right)$ & Enthalpy $\left(\mathbf{J . g}^{-1}\right)$ & $\mathbf{T}_{\text {id }}\left({ }^{\circ} \mathbf{C}\right)$ & $\mathbf{T}_{\mathbf{m}}\left({ }^{\circ} \mathbf{C}\right)$ & $\mathbf{T}_{\text {fd }}\left({ }^{\circ} \mathbf{C}\right)$ \\
\hline PCL & 58.6 & 34.9 & 333.0 & 403.4 & 434.0 \\
PCL + biopeptides & 56.8 & 28.6 & 262.3 & 318.0 & 339.6 \\
\hline $\mathrm{T}_{\text {melting }}:$ melting temperature of the nanofibers; $\mathrm{T}_{\mathrm{id}}$ initial degradation temperature of nanofibers; $\mathrm{T}_{\mathrm{m}}:$ average degradation temperature of nanofibers; \\
$\mathrm{T}_{\mathrm{fd}}:$ Final degradation temperature of nanofibers.
\end{tabular}


The changes in thermal parameters evaluated by DSC and TGA analysis are not harmful when obtaining nanofibers aimed for application in packaging. Thus, one can define that the processing of nanofibers and their applicability should be performed below $260{ }^{\circ} \mathrm{C}$. Obtaining biopeptide-added nanofibers by electrospinning is suitable because it does not use high temperatures in the process. Thus, biopeptides are not denatured and the maintenance of the activity for application as packaging occurs. The information about the thermal parameters are important to define the possible applications, as well as recycling and disposal. Moreover, the stability characteristics of nanofibers have potential for food packaging and the degradability that biopolymers are beneficial to have reduced environmental problems ${ }^{[34]}$.

Mechanical properties of PCL and biopeptide-added PCL nanofibers were evaluated. The thickness of the films were 0.50 and $0.16 \mathrm{~mm}$ for PCL and biopeptide-added PCL nanofibers, respectively. This difference is due to the nanofibers were randomly produced in flat collectors without alignment, and have not been disposed homogeneously in the collector occurred the emergence of areas with the greatest amount of nanofibers, which probably caused the values for the tensile strength presented inferior results to those found in other studies.

The tensile strength values are dependent on the maximum force applied to the material for the rupture to occur and cross-sectional area of the matrix of nanofibers. The tensile strength and elongation differences are directly linked to the thickness of the matrix of nanofibers. PCL and biopeptide-added PCL nanofibers showed tensile strengths of $0.137 \mathrm{MPa}$ and $0.245 \mathrm{MPa}$, and elongation of $85 \%$ and $64 \%$, respectively. Johnson et al. ${ }^{[35]}$ obtained tensile strength of $1.29 \mathrm{MPa}$ and elongation of $102 \%$ to nanofibers formed from $12 \%$ PCL solution. This value was higher than that obtained in this study because the authors used acetone under heating $\left(50^{\circ} \mathrm{C}\right)$ for the preparation of the polymer solution. The change of the interaction between solvent and polymer may form a distinct organization in the formed polymer chains which directly influences the properties of nanofibers.

In a study by Ghasemi-Mobarakeh et al. ${ }^{[36]}$ was obtained tensile strength of $3 \mathrm{MPa}$ to PCL nanofibers and when was added gelatin in PCL nanofibers was observed that there was a reduction in tensile strength,resulting in less than $1 \mathrm{MPa}$. This occurred due to the gelatin is a natural polymer that presents inferior mechanical properties compared to PCL nanofibers resulting in less mechanical strength than pure PCL nanofiber. This same event was observed in the present study when biopeptide-added in nanofibers.

For the DPPH method, there was no significant difference of the inhibition percentage between unhydrolyzed biomass and biopeptide-added nanofibers (Table 2). The ABTS sequestration methods and reducing power showed significant differences for the samples analyzed, showing increased antioxidant activity of the compounds after hydrolysis (Table 2). The increased activity of the peptides in relation to biomass was expected, due to be produced via intracellular by the biomass may have masked their activity.

The reduction of antioxidant activity after the electrospinning process was observed in all methods. The reduction may be associated with losses during the process of production das nanofibras and also on obtaining of the extracts for quantification of antioxidant activity. Likewise, the nanofiber matrix is composed of only $3 \%$ $(\mathrm{w} / \mathrm{v})$ biopeptides corresponding to $0.21 \mathrm{mg} \cdot \mathrm{mL}^{-1}$ of the compound in the extract while in the analysis of the pure compound, $5 \mathrm{mg} \cdot \mathrm{mL}^{-1}$ and $10 \mathrm{mg} \cdot \mathrm{mL}^{-1}$ of biopeptides were used. Still, biopeptides contained in PCL nanofibers showed antioxidant activity for all three methods studies.

Sheih et al. ${ }^{[37]}$ in a study to obtain biopeptides from seaweed residues obtained compounds of a molecular mass of $1.3 \mathrm{kDa}$ and tested the activity against DPPH and ABTS methods. The authors obtained $50 \%$ sequestration of these radicals at low concentrations of approximately $10 \mu \mathrm{g} \cdot \mathrm{mL}^{-1}$ when compared with synthetic antioxidants.

Cian et al. ${ }^{[38]}$ studied the bioactivity of purified peptides obtained by hydrolysis of the algae Porphyracolumbina and showed values of $50 \%$ inhibition of DPPH and ABTS radicals at concentrations of approximately $3 \mathrm{mg} \cdot \mathrm{mL}^{-1}$. The antioxidant activity of biopeptides obtained from Spirulina sp. LEB 18 were significant, since at low concentrations it was possible to obtain non-purified biopeptides with antioxidant activity against the tested methods.

Figure 4 shows the chicken meat samples with application of nanofiber matrix with biopeptides and the control. The control sample without nanofiber coating showed significant difference $(\mathrm{p}<0.05)$ in the content of malondialdehyde and total volatile bases compared to chicken meat samples stored with nanofibers. These figures show that the chicken meat without coating showed higher production of compounds derived from lipid oxidation (Table 3 ).

The application of nanofibers with antioxidant biopeptides in chicken meat was efficient during storage and reduced degradation of the sample. Nanofibers have greater surface area contact compared to their polymeric counterparts in macroscopic scale. Thus, the bioactive compounds showed higher reactivity with the degradation products aiding in product quality maintenance ${ }^{[15]}$.

The use of nanocomposites in the food packaging industry is promising since it greatly enhances the shelf life of products such as meats, cheeses, fruits and cereals ${ }^{[39]}$. In this study it is observed that the application of nanofibers

Table 2. Antioxidant activity of biomass, biopeptides and PCL and biopeptide-added PCL nanofibers.

\begin{tabular}{cccc}
\hline Sample & DPPH (\%Inhibition) & ABTS (\%Inhibition) & Poder Redutor (U.A., $\lambda=700 \mathbf{~ n m )}$ \\
\hline Biomass & $28.3 \pm 3.8^{\mathrm{a}, \mathrm{b}}$ & $26.5 \pm 1.7^{\mathrm{b}}$ & $0.415 \pm 0.015^{\mathrm{b}}$ \\
Biopeptides & $30.6 \pm 1.1^{\mathrm{a}}$ & $58.3 \pm 0.9^{\mathrm{a}}$ & $0.677 \pm 0.007^{\mathrm{a}}$ \\
PCL & $-* *$ & $-* *$ & $0.006 \pm 0.001^{\mathrm{d}}$ \\
PCL + biopeptides & $22.6 \pm 2.9^{\mathrm{b}}$ & $12.4 \pm 0.6^{\mathrm{c}}$ & $0.182 \pm 0.024^{\mathrm{c}}$ \\
\hline
\end{tabular}

Different letters in the same column represent statistically different results $(\mathrm{p}<0.05)$; $-* *$ : absorbance values were used as a blank for the calculation of $\%$ inhibition of DPPH and ABTS radicals. 


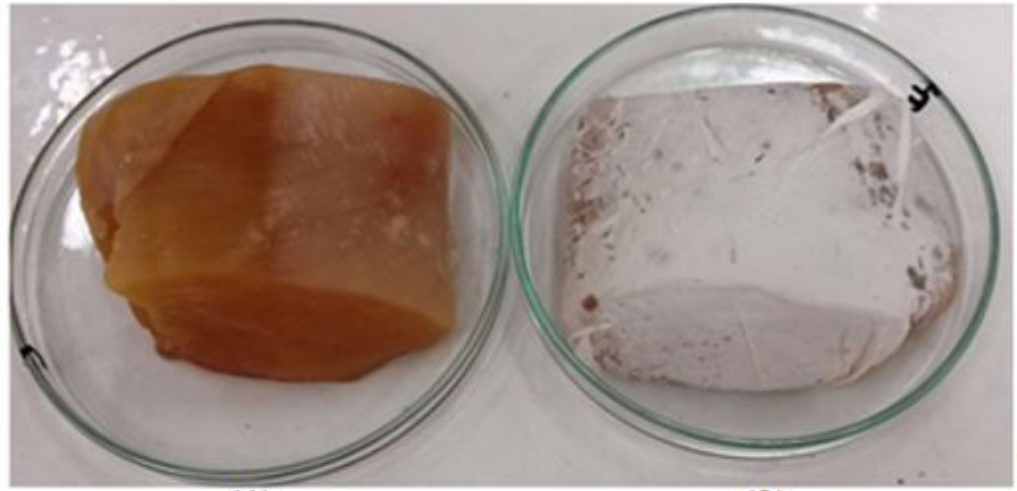

(a)

(1)

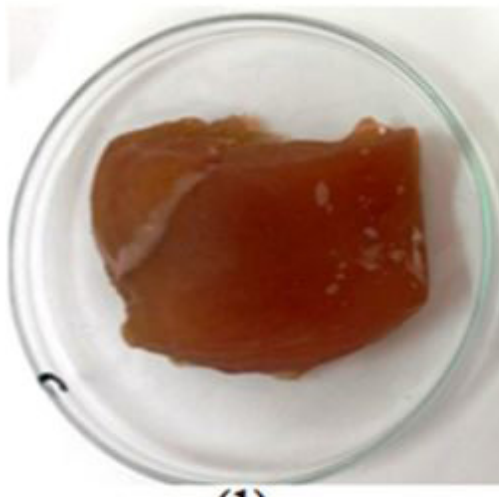

(1)
(2)

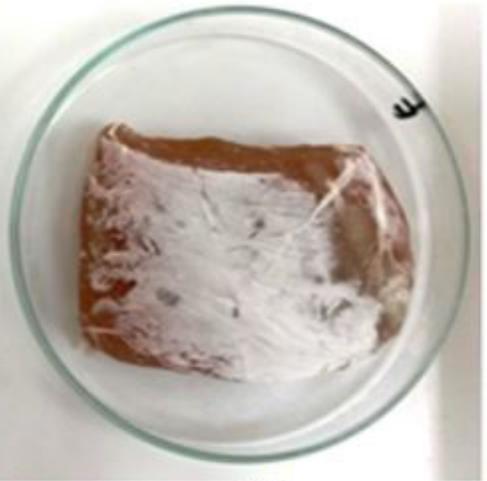

(2)

(b)

Figure 4. Control chicken cuts (1) and with nanofibers (2) containing biopeptides after 0 (a) and $12 \mathrm{~d}$ (b) of storage.

Table 3. TBARS analysis and N-BVT for samples containing nanofibers with biopeptides and the control after $12 \mathrm{~d}$ of storage.

\begin{tabular}{ccc}
\hline Sample & TBARS(mgMDA*kg-1) & N-BVT $\left(\mathbf{m g N} \cdot \mathbf{1 0 0 g}^{-1}\right)$ \\
\hline Control $(0 \mathrm{~d})$ & $0.3 \pm 0.0^{\mathrm{c}}$ & $25.1 \pm 0.7^{\mathrm{b}}$ \\
Control $(12 \mathrm{~d})$ & $2.6 \pm 0.0^{\mathrm{a}}$ & $33.8 \pm 0.0^{\mathrm{a}}$ \\
PCL + biopeptides & $1.0 \pm 0.0^{\mathrm{b}}$ & $25.8 \pm 0.3^{\mathrm{b}}$ \\
(12 d) & &
\end{tabular}

Different letters in the same column represent statistically different results $(\mathrm{p}<0.05)$

with biopeptides maintained the conservation of the product during the storage period evaluated while the sample without nanofiber coating showed values above those considered normal for maintaining the organoleptic characteristics of chicken meat.

Counsell and Horning ${ }^{[40]}$ reported that at TBARS values above $2 \mathrm{mg}$ malondialdehyde per $\mathrm{kg}$ sample, rancid odors are detected by untrained judges. Bazargani-Gilani et al. ${ }^{[41]}$ studied the stability of chicken breast coated with chitosan enriched with antioxidant plant extracts during storage under refrigeration. The application of natural antioxidants controlled oxidative processes during storage presenting potential for conservation of samples.

When coated with nanofibers containing biopeptides, chicken meat presented control in the process of degradation and values below those set as a limit by law. The quantification of volatile bases is generally regulated for fish. There is no current legislation to determine the N-BVT content of chicken meat cuts. Some studies show that levels above $30 \mathrm{mgN} \cdot 100 \mathrm{~g}^{-1}$ give the product sensory changes making it to be considered as not suitable for human consumption ${ }^{[42]}$.

\section{Conclusions}

The nanofibers containing biopeptides of microalgal origin presented a diameter of $438 \mathrm{~nm}$ and due to the large surface area of contact can be applied in food preservation. In the assays of stability of chicken cuts with the application of nanofibers containing biopeptides, there was control in the lipid oxidation process with values of $1.0 \pm 0.0 \mathrm{mgMDA} \cdot \mathrm{kg}^{-1}$ and $25.8 \pm 0.3 \mathrm{mgN} \cdot 100 \mathrm{~g}^{-1}$ compared with the control sample which showed $2.6 \pm 0.0 \mathrm{mgMDA} \cdot \mathrm{kg}^{-1}$ and $33.8 \pm 0.0 \mathrm{mgN} \cdot 100 \mathrm{~g}^{-1}$. Thus, PCL nanofiber matrices containing biopeptides with antioxidant activity are potential alternatives for use as primary active packaging with the aim of conservation of food products.

\section{Acknowledgements}

The authors would like to thank CAPES - Coordenação de Aperfeiçoamento de Pessoal de Nível Superior, CNPqConselho Nacional de Pesquisa Científica e Tecnológica, MCTI - Ministério da Ciência, Tecnologia e Inovação and CEME-SUL - Centro de Microscopia Eletrônica do Sul for their financial support for this study. 


\section{References}

1. Osawa, C. C., Felício, P. E., \& Gonçalves, L. A. G. (2005). Teste de tba aplicado a carnes e derivados: métodos tradicionais, modificados e alternativos. Quimica Nova, 28(4), 655-663. http://dx.doi.org/10.1590/S0100-40422005000400019.

2. Radha krishnan, K., Babuskin, S., Azhagu Saravana Babu, P., Sasikala, M., Sabina, K., Archana, G., Sivarajan, M., \& Sukumar, M. (2014). Antimicrobial and antioxidant effects of spice extracts on the shelf life extension of raw chicken meat. International Journal of Food Microbiology, 171, 32-40. PMid:24308943. http://dx.doi.org/10.1016/j.ijfoodmicro.2013.11.011.

3. Alix, S., Mahieu, A., Terrie, C., Soulestin, J., Gerault, E., Feuilloley, M. G. J., Gattin, R., Edon, V., Ait-Younes, T., \& Leblanc, N. (2013). Active pseudo-multilayered films from polycaprolactone and starch based matrix for food-packaging applications. European Polymer Journal, 49(6), 1234-1242. http://dx.doi.org/10.1016/j.eurpolymj.2013.03.016.

4. Azlin-Hasim, S., Cruz-Romero, M. C., Morris, M. A., Cummins, E., \& Kerry, J. P. (2015). Effects of a combination of antimicrobial silver low density polyethylene nanocomposite films and modified atmosphere packaging on the shelf life of chicken breast fillets. Food Packaging and Shelf Life, 4, 26-35. http://dx.doi.org/10.1016/j.fps1.2015.03.003.

5. Martínez-Abad, A., Sánchez, G., Fuster, V., Lagaron, J. M., \& Ocio, M. J. (2013). Antibacterial performance of solvent cast polycaprolactone (PCL) films containing essential oils. Food Control, 34(1), 214-220. http://dx.doi.org/10.1016/j. foodcont.2013.04.025.

6. Neo, Y. P., Ray, S., Jin, J., Gizdavic-Nikolaidis, M., Nieuwoudt, M. K., Liu, D., \& Quek, S. Y. (2013). Encapsulation of food grade antioxidant in natural biopolymer by electrospinning technique: A physicochemical study based on zein-gallic acid system. Food Chemistry, 136(2), 1013-1021. PMid:23122157. http://dx.doi.org/10.1016/j.foodchem.2012.09.010.

7. Wu, J. C. C., Ray, S., Gizdavic-Nikolaidis, M., Uy, B., Swift, S., Jin, J., \& Cooney, R. P. (2014). Nanostructured bioactive material based on polycaprolactone and polyaniline fiber-scaffolds. Synthetic Metals, 198, 41-50. http://dx.doi. org/10.1016/j.synthmet.2014.09.017.

8. Kim, S. K., \& Wijesekara, I. (2010). Development and biological activities of marine-derived bioactive peptides: a review. Journal of Functional Foods, 2(1), 1-9. http://dx.doi. org/10.1016/j.jff.2010.01.003.

9. Morais, M. G., Vaz, B. S., Morais, E. G., \& Costa, J. A. V. (2015). Biologically active metabolites synthesized by microalgae. BioMed Research International, 2015, 835761. PMid:26339647. http://dx.doi.org/10.1155/2015/835761.

10. Lisboa, C. R., Pereira, A. M., Ferreira, S. P., \& Costa, J. A. V. (2014). Utilisation of Spirulina sp. and Chlorella pyrenoidosa biomass for the production of enzymatic protein hydrolysates. Journal of Engineering Research and Applications, 4(1), 29-38.

11. Korhonen, H. (2009). Milk-derived bioactive peptides: From science to applications. Journal of Functional Foods, 1(2), 177-187. http://dx.doi.org/10.1016/j.jff.2009.01.007.

12. Mills, S., Stanton, C., Hill, C., \& Ross, R. P. (2011). New developments and applications of bacteriocins and peptides in foods. Annual Review of Food Science and Technology, 2(1), 299-329. PMid:22129385. http://dx.doi.org/10.1146/ annurev-food-022510-133721.

13. Bhushani, J. A., \& Anandharamakrishnan, C. (2014). Electrospinning and electrospraying techniques: Potential food based applications. Trends in Food and Technology, 38(1), 21-33. http://dx.doi.org/10.1016/j.tifs.2014.03.004.

14. Takala, P. N., Vu, K. D., Salmieri, S., Khan, R. A., \& Lacroix, M. (2013). Antibacterial effect of biodegradable active packaging on the growth of Escherichia coli, Salmonella typhimurium and Listeria monocytogenes in fresh broccoli stored at $4{ }^{\circ} \mathrm{C}$. Lebensmittel-Wissenschaft + Technologie, 53(2), 499-506. http://dx.doi.org/10.1016/j.lwt.2013.02.024.

15. Azeredo, H. M. C. (2013). Antimicrobial nanostructures in food packaging. Trends in Food Science \& Technology, 30(1), 56-59. http://dx.doi.org/10.1016/j.tifs.2012.11.006.

16. Kim, M. S., \& Kim, G. (2014). Three-dimensional electrospunpolycaprolactone (PCL)/alginatehybrid composite scaffolds. Carbohydrate Polymers, 114, 213-221. PMid:25263884. http://dx.doi.org/10.1016/j.carbpol.2014.08.008.

17. Morais, M. G., Radmann, E. M., Andrade, M. R., Teixeira, G. G., Brusch, L. R. F., \& Costa, J. A. V. (2009). Pilot scale semicontinuous production of Spirulina biomass in southern Brazil. Aquaculture, 294(1-2), 60-64. http://dx.doi.org/10.1016/j. aquaculture.2009.05.009.

18. Hoyle, N. T., \& Merritt, J. H. (1994). Quality of fish protein hydrolysate from herring (Clupeaharengus). Journal of Food Science, 59(1), 76-79. http://dx.doi.org/10.1111/j.1365-2621.1994. tb06901.x.

19. American Society for Testing and Materials - ASTM. (2010). ASTM E986-04: Standard practice for scanning electron microscope beam size characterization. West Conshohocken: ASTM.

20. American Society for Testing and Materials - ASTM. (2013). ASTM D7426-08: Standard test method for assignment of the DSC procedure for determining Tg of a polymer or an elastomeric compound. West Conshohocken: ASTM.

21. American Society for Testing and Materials - ASTM. (2013). ASTM D3850-12: Standard test method for rapid thermal degradation of solid electrical insulating materials by thermogravimetric method (TGA). West Conshohocken: ASTM.

22. Wu, H. C., Chen, H. M., \& Shiau, C. Y. (2003). Free amino acids and peptides as related to antioxidant properties in protein hydrolysates of mackerel (Scomberaustriasicus). Food Research International, 36(9-10), 949-957. http://dx.doi.org/10.1016/ S0963-9969(03)00104-2.

23. Brand-Williams, W., Cuvelier, M. E., \& Berset, C. (1995). Use of a free radical method to evaluate antioxidant. LebensmittelWissenschaft + Technologie, 28(1), 25-30. http://dx.doi. org/10.1016/S0023-6438(95)80008-5.

24. Rufino, M. S. M., Alves, R. E., Brito, E. S., Morais, S. M., Sampaio, C. G., Pérezjiménez, J., \& Saura-Calixto, F. D. (2007). Metodologia científica: determinação da atividade antioxidante total em frutas pela captura do radical livre $A B T S^{+}$(Comunicado técnico 128). Fortaleza: EMBRAPA.

25. Crackel, R. L., Gray, I. J., Pearson, A. M., Booren, A. M., \& Buckley, O. J. (1988). Some further observations on the TBA. Test as an index of lipid oxidation in meats. Food Chemistry, 28(3), 187-196. http://dx.doi.org/10.1016/0308-8146(88)900507.

26. Association of Official Analytical Chemists - AOAC. (1990). AOAC: Official methods of analysis. Washington: AOAC.

27. Collins, G., Federici, J., Imura, Y., \& Catalani, L. H. (2012). Charge generation, charge transport, and residual charge in the electrospinning of polymers: a review of issues and complications. Journal of Applied Physics, 111(2), 047701. http://dx.doi.org/10.1063/1.3682464.

28. Ranjbar-Mohammadi, M., \& Bahrami, S. H. (2015). Development of nanofibrous scaffolds containing gum tragacanth/poly $(\varepsilon-$ caprolactone) for application as skin scaffolds. Materials Science and Engineering C, 48, 71-79. PMid:25579898. http:// dx.doi.org/10.1016/j.msec.2014.10.020.

29. Goes, A. M., Carvalho, S., Oréfice, R. L., Avérous, L., Custódio, T. A., Pimenta, J. G., Souza, M. B., Branciforti, M. C., \& 
Bretas, R. E. S. (2012). Viabilidade celular de nanofibras de polímeros biodegradáveis e seus nanocompósitos com argila montmorilonita. Polímeros: Ciência e Tecnologia, 22(1), 3440. http://dx.doi.org/10.1590/S0104-14282012005000012.

30. Campos, A., Marconato, J. C., \& Franchetti, S. M. M. (2010). Biodegradação de filmes de PP/PCL em solo e solo com chorume. Polimeros: Ciência e Tecnologia, 20(4), 295-300. http://dx.doi.org/10.1590/S0104-14282010005000039.

31. Wang, X., Haibin, Z., \& Turng, L. S. (2013). Crystalline morphology of electrospunPoly ( $\varepsilon$-caprolactone) (PCL) nanofibers. Industrial \& Engineering Chemistry Research, 52(13), 4939-4949. http://dx.doi.org/10.1021/ie302185e.

32. Ciardelli, G., Chiono, V., Vozzi, G., Pracella, M., Ahluwalia, A., Barbani, N., Cristallini, C., \& Giusti, P. (2005). Blends of poly-( $\varepsilon$-caprolactone) and polysaccharides in tissue engineering applications. Biomacromolecules, 6(4), 1961-1976. PMid:16004434. http://dx.doi.org/10.1021/bm0500805.

33. Patrício, T., Domingos, M., Gloria, A., D'amora, U., Coelho, J. F., \& Bártolo, P. J. (2014). Fabrication and characterisation of PCL and PCL/PLA scaffolds for tissue engineering. Rapid Prototyping Journal, 20(2), 145-156. http://dx.doi.org/10.1108/ RPJ-04-2012-0037.

34. Duarte, M. A. T., Hugen, R. G., Martins, E. S., Pezzin, A. P. T., $\&$ Pezzin, S. H. (2006). Thermal and Mechanical behavior of injection molded poly(3-hydroxybutyrate)/poly( $\varepsilon$-caprolactone) blends. Materials Research, 9(1), 15-27. http://dx.doi.org/10.1590/ S1516-14392006000100006.

35. Johnson, J., Niehaus, A., Nichols, S., Lee, D., Koepsel, J., Anderson, D., \& Lannutti, J. (2009). Electospun PCL in vitro: a microstructural basis for mechanical property changes. Journal of Biomaterials Science, 20(4), 467-481. PMid:19228448. http://dx.doi.org/10.1163/156856209X416485.

36. Ghasemi-Mobarakeh, L., Prabhakaran, M. P., Morshed, M., Nesr-Esfahani, M. H., \& Ramakrishna, S. (2008).
Electrospun poly(epsilon-caprolactone)/gelatin nanofibrous scaffolds for nerve tissue engineering. Biomaterials, 29(34), 4532-4539. PMid:18757094. http://dx.doi.org/10.1016/j. biomaterials.2008.08.007.

37. Sheih, I. C., Wu, T. K., \& Fang, T. J. (2009). Antioxidant properties of a new antioxidative peptide from algae protein waste hydrolysate in different oxidation systems. Bioresource Technology, 100(13), 3419-3425. PMid:19299123. http:// dx.doi.org/10.1016/j.biortech.2009.02.014.

38. Cían, R. E., Martínez-Augustin, O., \& Drago, S. R. (2012) Bioactive properties of peptides obtained by enzymatic hydrolysis from protein byproducts of Porphyracolumbina. Food Research International, 49(1), 364-372. http://dx.doi org/10.1016/j.foodres.2012.07.003.

39. Rhim, J. W., Park, H.-M., \& Ha, C.-S. (2013). Bio-nanocomposites for food packaging applications. Progress in Polymer Science, 38(10-11), 1629-1652. http://dx.doi.org/10.1016/j. progpolymsci.2013.05.008

40. Counsell, J. N., \& Horning, D. H. (Eds.) (1981). Vitamin C (ascorbis acid) (Chap. 7). London: Applied Science Ltd.

41. Bazargani-Gilani, B., Aliakbarlu, J., \& Tajik, H. (2015). Effect of pomegranate fruit juice dipping and chitosan coating enriched with Zataria multiflora Boiss essential oil on the quality shelf life of chicken breast meat during refrigerated storage. Innovative Food Science and Emerging Technologies, 29, 280-287.

42. Brasil. Ministério da Agricultura Pecuária e Abastecimento. (1980). Regulamento da Inspeção Industrial e Sanitária de Produtos de Origem Animal. (RIISPOA). Brasília: MAPA.

Received: Nov. 09, 2015

Revised: Mar. 18, 2016

Accepted: May 17, 2016 